\title{
22. Elections and Corruption: The 'Highlandization' of Voting in the Madang Open and Provincial Electorates
}

\author{
Patrick Matbob
}

\section{Introduction}

Elections in the coastal areas of Papua New Guinea are generally free, fair and orderly compared to the Highlands provinces. This was again observed during the 2007 election, in which almost all coastal provinces experienced smooth and orderly conduct of elections. However, while most of the seats were declared before the return of writs, Madang was the only coastal province that could not declare its Provincial seat because of a court injunction taken out by some candidates. The return of writs had to be deferred by a week until the court had ruled on the case, subsequently allowing the declaration of Sir Arnold Amet. The court dispute that delayed the declaration of the Madang Provincial seat is symptomatic of the influence that is coming into the province and is affecting local politics.

In the past decade an increasing number of candidates originally from the Highlands provinces have been contesting the Madang Open and Madang Provincial electorates (Figures 22.1 and 22.2). These candidates have brought with them the style of politics that is widely practised in the Highlands of Papua New Guinea. Standish (2002b:2) reports discussion of Highlands-style politics experienced in some coastal electorates in 2002. Madang has recently been experiencing this Highlands style of politics which has affected the electoral process. It includes massive inflation of the electoral roll, multiple voting, the use of large sums of money, and, in some cases, firearms. The so-called 'highlandisation of coastal politics' (Standish 2003:131) is created by candidates who are determined to gain public office at all cost and by whatever means. And if they are unsuccessful, they try to disrupt the process and challenge the duly elected member. 


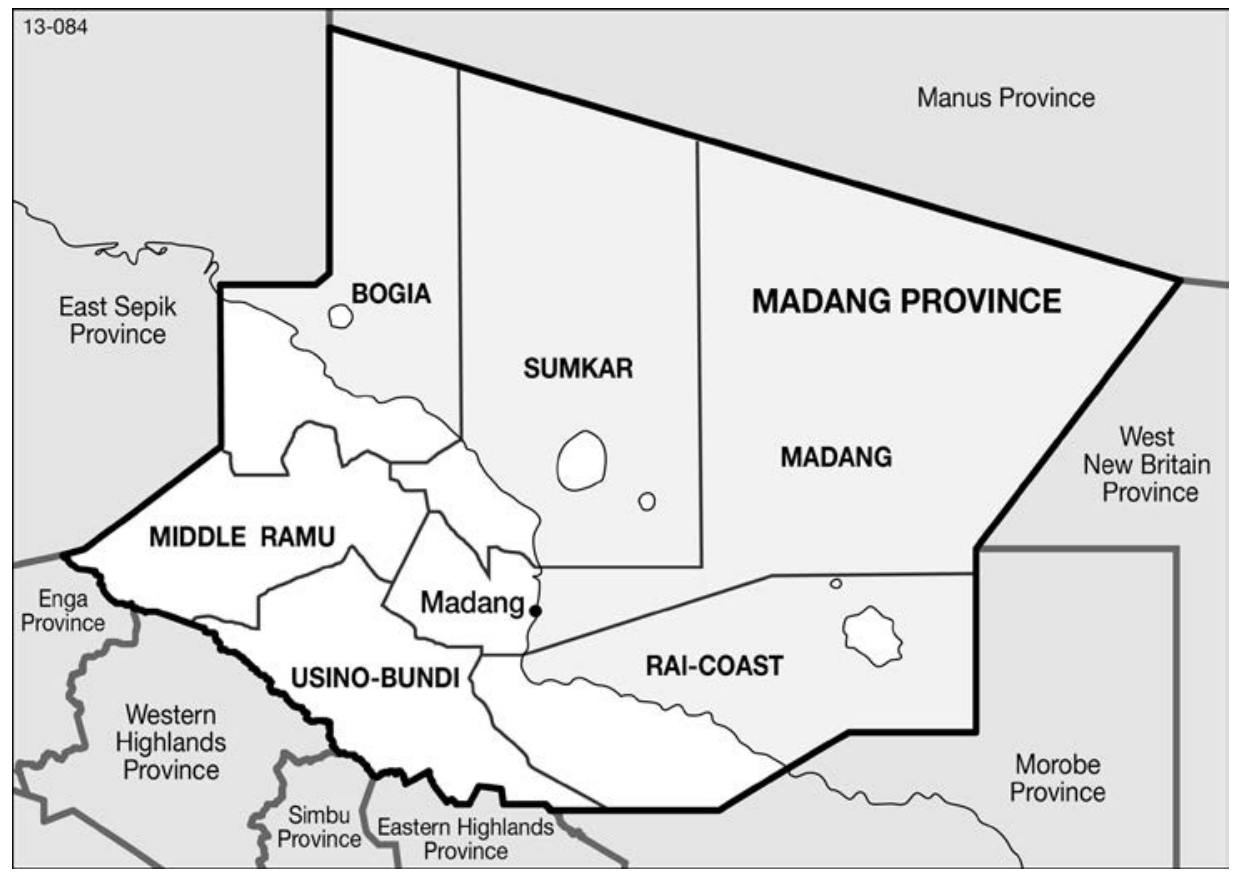

Figure 22.1: Madang Province open electorates

Standish describes a similar situation in Simbu as an 'ethics-free zone' where 'candidates will do whatever it takes in attempting to grab state power' (Standish 2002a:28). This has little to do with representing the interests of the people or following legitimate political processes to gain office, although this is the rhetoric that is publicly expounded. Money is a key issue, and usually if one is rich enough one can buy one's way to power and pay off rivals and challengers to silence them (see Sinclair 2006:366). And if one has spent a lot of money only to lose, then one continues the challenge until there is a compromise with the winner and some cost is recovered. The study of Madang Open and Madang Provincial electorates in 2007 looks at some of these issues.

\section{Background to the Madang Provincial and Madang Open seats}

\section{Madang Province}

The Madang Provincial seat was won by Jason Garrett in 1968 (Table 22.1). He later lost to cattle rancher Bruce Jephcott, who held the seat for two consecutive terms (1972-1982). A Madang man, Tom Pais, won the seat in 1982. Melchior Kasap originally won the seat in 1987 but was replaced by Tom Pais following 
a court decision in 1988. Pais was succeeded by Sir Peter Barter in 1992, Jim Kas in 1997, and Sir Peter Barter again in 2002. Evidently, those who succeeded in the Provincial seat were the 'better known' candidates, either because they were businessmen like Barter who had the resources to campaign widely, or people like Melchior Kasap, whose job in Catholic Church education enabled him to have wide contact with the people in the province. Madang's diverse geography has meant that to cover all parts of the electorate one needed to travel by air, sea and land, and that made it too expensive for many candidates to campaign widely.

Although regional/provincial members have represented Madang since 1968, after independence they did not have much influence in the province. The provincial governments introduced after independence became the centres of power and diminished the role and mandate of the national parliamentariansin particular the backbenchers. This eventually led to the call for provincial government reforms (Gupta and Ivarature 1996; May and Regan 1997).

Table 22.1: Members for Madang Provincial and Madang Open, 1968 to 2007

\begin{tabular}{llll}
\hline Madang Provincial & \multicolumn{2}{l}{ Madang Open } \\
\hline 1968 & Jason Garrett & 1968 & John Middleton \\
1972 & Bruce Jephcott & 1972 & Angmai Bilas \\
1978 & Bruce Jephcott & 1978 & Angmai Bilas \\
1982 & Tom Pais & 1982 & Paul Kamod \\
1987 & Tom Pais & 1987 & Paul Kamod \\
1992 & Sir Peter Barter & 1992 & Stanley Pil \\
1997 & Jim Kas & 1997 & Jacob Wama \\
2002 & Sir Peter Barter & 2002 & Alois Kingsley \\
2007 & Sir Arnold Amet & 2007 & Buka Malai \\
\hline
\end{tabular}

From 1978 Madang had in place an active provincial government system headed by the first premier, Bato Bultin. Bultin was succeeded by Max Moeder, Andrew Ariako and Mathew Gubag respectively. On 19 July 1995, provincial government reforms were certified, taking full effect on 16 October 1997. One of the changes was to replace the office of the premier with a governor. Unfortunately, for Madang the reform had a negative effect, especially with the quality of leadership displayed by governors, which caused widespread embarrassment and disillusionment among the voters. Regional member, Sir Peter Barter, who became governor immediately after the reform, was the ideal people's choice; however, he had to relinquish the post when he became Minister for Inter-Government Relations, and the governor's position went to Usino-Bundi member of parliament (MP) George Wan. 
In 1997, Jim Kas defeated Sir Peter Barter and became the governor of the province. A university graduate from Simbai, Kas worked as a provincial government officer before entering politics and epitomized the emergence of the new breed of well-educated young leaders in Papua New Guinea. However, the promise was short lived; barely a year later Kas was gaoled for four years for 'endangering the free and safe use of an aircraft at Madang Airport' (Sinclair 2005:371). Deputy Governor Pengau Nengo took over as acting governor until 1999 when Kas was released. Despite opposition from the provincial assembly, who wanted him removed as governor, Kas was able to resume his position. Soon he was in trouble again, this time being involved in a road accident in which a person was killed. Although Kas's conviction over the airport incident was set aside by the Supreme Court, he was convicted of a serious breach of Papua New Guinea's Leadership Code and was removed from the office of governor. Pengau Nengo took over as acting governor. There followed a struggle between former governor George Wan and Rai Coast MP Stahl Musa for the governor's post, with Musa eventually emerging as the governor. He remained in the position until 2002.

Sir Peter Barter won back the governor's seat in the 2002 election but again opted for a ministry in the national government, and was replaced by the new member for Rai Coast, James Yali. Yali, the adopted son of the late cargo cult leader Yali Singina, became a controversial figure and did not last long. In January 2006 he was convicted and sentenced to 12 years imprisonment for raping his sister-in-law (see The State $v$ James Yali, 2005). The province was again under the care of an acting governor, Bunag Kiup, up until the 2007 national elections. The behaviour of the governors since the reforms, and also of other Madang MPs such as Jacob Wama, who was jailed for eight years in 2002 for misappropriating K150,000 of public funds (The State $v$ Jacob Wama Kelewaki, 2001), tarnished the image of leaders in Madang. People viewed the political leadership with cynicism, and there was even a belief that the governor's seat had become cursed.

\section{Madang Open}

The Madang town electorate is divided into three local-level government (LLG) areas: Madang Urban, Ambenob and Transgogol (Figure 22.2). Madang Urban caters for the town and some of the Bell people in the islands and around the town; Ambenob covers Amele, the rest of the Bell, and the north coast as far as Vidar; Transgogol covers further south and extends into the hinterland of Madang. 


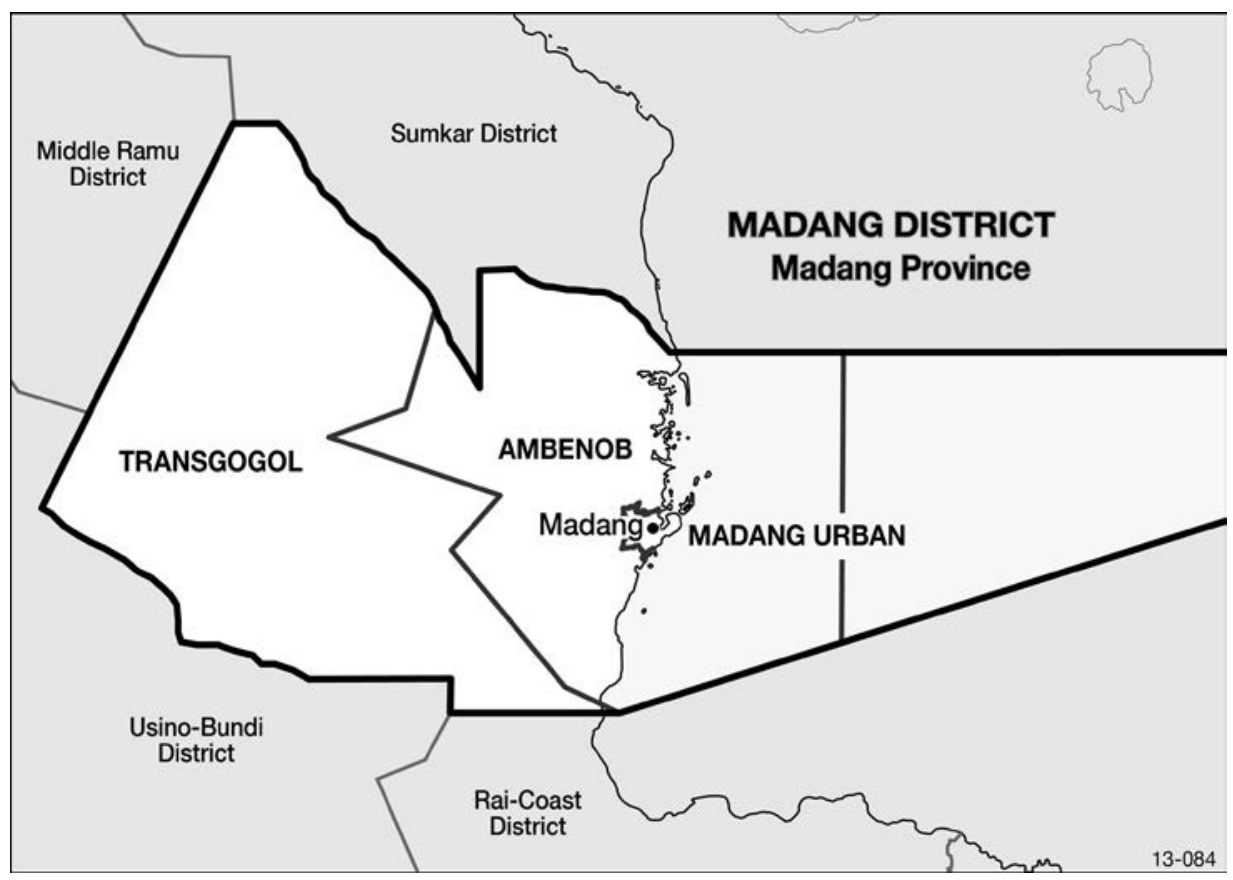

\section{Figure 22.2: Madang District}

The large number of languages (164) in the province is also an indication of the fragmentation of ethnic groups (SIL 2009). This has caused factionalism during elections, with villagers splitting up their votes. The candidates with a wider appeal tend to do better. Since 1992 MPs for Madang Open have been people from other provinces residing in the town who have had support from both the urban and rural areas of the electorate.

When explaining the misconceptions of ethnicity, Nelson (2006) writes that while a large number of languages indicates diversity, it does not justify the slide from language groups to ethnic fragmentation and explanations of political process'.

What confounds democracy in most electorates is not ethnicity, but smaller groups, often called clans and formed by people who have or assume a common ancestry (Nelson 2006:10).

Nelson uses an example from the Highlands to show that in contemporary politics there is a link between voting blocs and groups that form alliances in defence and aggression. However, the coastal Madang people have enjoyed a peaceful existence well before the arrival of European explorers. Alliances for tribal warfare, or even against colonial invaders, are generally unknown. Candidates in Madang, however, face the same problems that those in the Highlands encounter, which is to maintain the support base of their home clan or 
tribe (Gibbs, cited in Nelson 2006:10). The limited number of voters in clan and language groups also means that for candidates to do well they have to attract support beyond their support base. ${ }^{1}$ Therefore, those who can appeal beyond their base votes have done well in the national elections since independence. Successful candidates have also been endowed with characteristics that Nelson (ibid.) has highlighted, such as personality, the capacity to bring material benefits, and religious appeal. Of course, those who have succeeded were also known to have given handouts in cash and kind to villagers and community groups.

Voters in Madang are generally free to choose who to vote for without pressure from family or clan members. The choice may, however, be limited by lack of knowledge of candidates, which is why those who campaign widely tend to do well. Sometimes family or clan groups may consult and agree to vote for certain candidates. The choice of candidates increased in the recent election because of limited preferential voting (LPV).

\section{Issues influencing the outcome of the 2007 election}

Madang Province is made up of diverse groups of people living along the coast, on the islands, and in the highlands of Usino-Bundi and Middle Ramu electorates, which border East Sepik, Enga, Western Highlands, Simbu and Eastern Highlands provinces. Those living in the highlands of Madang are ethnically related to people in Simbu, Western Highlands and Eastern Highlands, while those furthest north have ties with East Sepik people. Crossborder relationships also exist for southern coastal people with Morobe and West New Britain. Similarities were reported in the style of politics displayed in the highlands of Madang to the politics of the Highlands Region-for example, in Usino-Bundi candidates built 'election houses'.

\section{Land and squatters}

It was the Russian naturalist Mihlouho-Maclay who called the Madang coastal region which is part of Madang Open, the 'Archipelago of Contented People' (Sinclair 2005:8). Those who have followed have found the description to be generally accurate. The people living in the area have had a peaceful existence with their neighbours, trading clay pots, garden produce and seafood, and traditional artifacts and ornaments, within and beyond the boundaries of the

1 Similarly, see May (2006). 
present-day Madang electorate. European explorers and colonial administrators have found the people of Madang generally willing to accept outsiders and share their homeland.

In recent times, though, there has been growing discontent among the local people over land issues in Madang town and the influx of squatter settlers, leading to evictions. While these issues have existed in the past, the people affected by them had lived in fragmented groups and were not able to collectively voice their concerns. The Madang town land issue is a complex one dating back to the era of German colonial administration and concerns the manner in which large tracts of land within the present-day Madang Open electorate were 'purchased' without the knowledge or consent of the local people (Sinclair 2005:19). As a result, there have been disputes ever since between the colonial administration and the local people and also among the landowners themselves.

Further, with the growth of Madang town, migrants from within Madang Province and from neighbouring provinces, mainly East Sepik, have moved into Madang town and settled on vacant state land. The squatter population was estimated at 8120 in 2005, of whom 6000 were from East Sepik. They occupy portions of state land that are needed for development purposes (Sinclair 2005:375).

Initially, land issues and eviction were left to the provincial government and the police to deal with as a law and order problem. However, recently landowners and different ethnic groups in Transgogol and Ambenob have begun collaborating to deal with the issues, resulting in a protest march in support of evictions in 2003. One of the key leaders advocating the eviction of squatters was Morris Ban, a candidate for Madang Open in 2007. Issues of land and eviction have become a unifying factor for the fragmented groups of Madang people - primarily from South Ambenob, Madang Urban and parts of North Ambenob LLGs - and their actions ultimately had an effect on the 2007 election.

\section{Kam man versus asples}

In Madang, the Tokpisin term used to describe a squatter settler or someone not originally from Madang is kam man, literally a person who has come from outside the local area or province. The term asples refers to a landowner or a person originally from Madang. Asples and kam man became key words in the discourse leading up to and during the election.

The Madang Open and Madang Provincial electorates have been contested by kam man candidates, especially those originally from the Highlands, for more 
than a decade. In fact, the Madang Open seat has been held by a kam man since 1992 (Jacob Wama, originally from East Sepik, Stanley Pil from Western Highlands, and Alois Kingsley from Southern Highlands).

There has been a growing discontent among the asples people about the kam man MPs who have been voted in since 1992 and who the people felt had not really represented their interests. First, the fact that no asples candidate was able to win the seat for three terms of parliament was a blow to the pride of the local people. Then, the actions and behaviour of MPs angered the local voters. As noted above, Jacob Wama (1997-2002) was gaoled for misappropriating funds meant for local projects, while poor public behaviour by Alois Kingsley (20022007) was the subject of adverse media reports on several occasions. Governors Kas (1997-2002) and Yali (2002-2007) were also in trouble with the law at the time.

The domination of the Open seat by the kam man became an issue in the 2007 elections. The different ethnic groups within Madang began to express a united voice, which became the votim asples campaign (vote for the local Madang person rather than the kam man). LPV's feature of encouraging cooperation among candidates seems to have helped in enabling the local Madang candidates to unite against the outsiders. The votim asples feeling was strong among locals, although a number of villagers still chose to back the kam man candidates or vote along party lines because of benefits they have been receiving. The votim asples campaign was mainly championed by candidates and voters of the Transgogol and South Ambenob areas, while those in Madang Urban LLG and North Ambenob displayed a more tolerant attitude. There were, however, North Ambenob candidates who urged people to vote for an asples leader. The votim asples campaign was, however, up against some well-funded candidates who were determined to buy their way to victory.

\section{Highlandization of coastal politics}

In talking about the 'Highlandization' of coastal politics, (Standish 2003:131) identifies 'the mass inflation of the electoral roll, multiple voting and the use of large sums of money and, in some cases, firearms'. In Madang there has been growing evidence of the Highlands style of politics creeping into the province. This is not surprising since Madang is one of only two coastal provinces connected to the Highlands by road. As a result there has been an influx of highlanders into the province, encouraged by the betel nut trade as well as markets for fresh Highlands vegetables. There are also employment and business opportunities in the province because of the development of resource projects. 
The aggressive behaviour of highlanders seeking to participate in business, and in obtaining property and land, has alarmed the people of Madang who suspect that some of the highlanders' activities have not been transparent.

Evidence of Highlands-style politics in Madang has included incidents of bloc voting, roll stacking, multiple voting, large sums of money, and the use of firearms. While the incidents in Madang are isolated and insignificant in comparison with more dramatic events in Highlands elections, nevertheless they have been notable in the quieter politics of Madang. For example, as will be discussed below, an attempt was made to inflate the roll in Ward 5 by a $\mathrm{kam}$ man candidate originally from the Highlands. Instances of multiple voting in Madang have been reported in the media. The distribution of large sums of money by candidates was also noted before and during the campaigns, and the use of firearms in the election became a concern when certain candidates and their supporters, mainly from the Highlands provinces, tried to use weapons to influence the outcome of the elections.

In Madang early observation suggests that the creation of a new roll based on the local government council wards effectively controlled the possibilities of roll inflation. However, the Madang Open and Madang Provincial seats cover the urban area where there are large numbers of people. With the constant movement of people in and out of town, it is difficult to identify the exact number of people living in the wards. Assistant returning officer of the Madang Urban LLG, Laki Tonngi, saw this as a problem and said the urban wards' census books should be updated every six months and that full-time recorders were needed. Currently, ward recorders are on a K40 monthly allowance which, he said, was not sufficient; anybody could come and enrol and it would be hard to verify their residential status.

\section{The study of the 2007 election in Madang}

This study draws on direct observation of the 2007 election in parts of the Madang Open, Madang Provincial and Sumkar Open electorates, from enrolment up to the return of writs. A mini questionnaire survey was also distributed to Divine Word University and Madang Technical College students to obtain data on student voter behaviour, and random interviews were done with voters in Sumkar electorate (the home electorate of the candidate who was the favourite for the Provincial seat, Sir Arnold Amet).

The student questionnaire (of which only 42 were returned) was distributed after it was learnt that certain kam man candidates were trying to mobilize students' support and were offering them inducements in cash and kind. 
The questionnaire was divided into three parts, dealing with enrolment, campaigning, and the polling period. The findings of the study are summarized below.

\section{Votim asples campaign}

The votim asples campaign was carried out by a group of candidates mainly from South Ambenob LLG on the outskirts of Madang town. There was a strong feeling against kam man candidates among both the Madang villagers and people from other provinces residing in Madang, who questioned the character and intentions of some of the candidates and were of the view that local politics should remain in the hands of the asples people.

The Transgogol candidates campaigned throughout the electorate and their message was that while the kam man were welcome to live and work in Madang, they should stay away from politics which was only for the asples. At the close of nominations in May, at Madang Bates Oval there was a confrontation between the South Ambenob group of asples candidates led by former police officer Jim Namora and a former Madang MP, Stanley Pil - a kam man. The former MP turned up at the oval but did not proceed to the nearby Madang District Office to nominate. Instead, he summoned the Madang District Returning Officer, Gol Damud, to his rally to nominate him in front of his supporters, who were mainly settlers from the Gav Stoa area. This angered the Transgogol group who moved their supporters up next to the former MP's gathering and disrupted his campaign. Open anger was expressed by the South Ambenob group, who said that outsiders who came into Madang for business or work, or were married to local women should stay away from local politics. The confrontation resulted in the former MP being led away by his supporters to another part of the oval.

The campaign of the South Ambenob group continued throughout the campaign period. Morris Ban, a Madang Open candidate and member of the Transgogol group, told me that they would not tolerate kam man candidates and barred them from campaigning in South Ambenob and Transgogol areas. Although I had no opportunity to visit that part of the electorate, people from the area confirmed that kam man candidates did not campaign there. A journalist from the National Broadcasting Corporation told me that during the nomination period, a bigname kam man candidate's campaign at the popular Four-Mile market in South Ambenob was disrupted when the local people pelted the campaigners with objects and chased them back to town. 


\section{Campaign against vote buying}

There were civil society and candidate campaigns against vote buying and voters were asked to ignore candidates who attempted to bribe voters with cash, food and other goods. Candidate Jim Kas told voters that although food and money would be given to them, people should vote, using their heads, for an asples candidate. Similar sentiments were expressed by candidate Sam Aloi, who criticized the voters who were going after food and money because it was not the 'custom' of the Madang people. Aloi was also the only person who campaigned on the dangers of HIV/AIDS. Candidate Tony Birra told voters that they should not expect handouts from him because it was not the local custom. He said according to 'custom' people are rewarded with a celebration after an achievement - in this case an election victory. The irony of this was that some asples candidates were also guilty of offering inducements for votes.

\section{Deals over preferences}

Deals were most apparent among candidates and voters from South Ambenob. The group not only campaigned together and asked voters to share their preferences among them, but also campaigned against kam man candidates. A notable development was the series of meetings held among the asples candidates to reduce their numbers in order to increase their chances of winning. A local leader told me that at least three public meetings were held in South Ambenob and Transgogol and some candidates, including Catherine Mal, the only female and a popular asples candidate, stepped down as a result. However, Catherine subsequently supported a kam man candidate whom her people were campaigning against. It was obvious that the kam man was trying to attract Catherine's supporters in South Ambenob and Transgogol.

\section{Inducement to win votes}

A number of candidates within Madang Open, Madang Provincial and Sumkar used inducements in cash and kind to win votes. As usual in the period leading up to the elections, candidates sponsored sports teams, community groups, and events such as sports tournaments. One candidate even set up youth organizations called Youth-link. Various amounts of cash were dished out just before polling began at villages such as Yabob, Riwo, Siar and along the north coast. This was obvious at Divine Word University campus, which had some 800 eligible voters; students were the target of certain $\mathrm{kam}$ man candidates who distributed cash and promised benefits. The mini survey conducted among 42 students (23 females and 19 males) revealed that 23 of them had accepted 
inducements offered by kam man candidates, who asked for their vote. The inducements included cash amounts of from K2 to K600 and other benefits such as alcohol and free entry to dances.

\section{Students enrolled by candidate}

Of the 42 students surveyed, 29 were enrolled to vote; however, 12 said that they did not enrol themselves. Of the 12, nine said they were enrolled by a Highlands candidate while three said they had no idea how their names got on to the list. One said he had already enrolled himself but later found someone had re-enrolled him using incorrect data for his birth date. Some students said they did not want to vote in Madang and therefore had not enrolled, but were surprised to find their names on the roll. In fact, a check through the ward roll revealed more than 104 entries repeated, some more than three times. Other ward rolls in Madang did not show any multiple entries. Under the electoral law, those qualified to vote must complete and sign an enrolment form for their names to be included on the ward roll in their electorate of residence. This did not happen in Ward 5; the Highlands candidate collaborated with the ward recorder to enrol the students. A student who is a provincial group leader told me that a particular Highlands candidate had invited her and other group leaders to his residence for a meeting and asked them to give him a list of their student members so that he could enroll them. She said this is how the names of students were obtained. She said in return the student leaders were offered free entry to the candidate's nightclub. Cash and liquor were also offered. Most of the students interviewed accepted the inducements and said that they were poor and needed the cash and benefits. They said it was an opportunity not to be missed.

\section{Eviction threat}

Madang's population of settlers, mainly from East Sepik, again became a target in the campaigns of kam man, who promised that there would be no evictions should kam man candidates won. The night before polling, one confident campaigner told the settlers at Gav Stoa that he wanted their second preferences only and asked them to sell their first preference votes to the highest bidder. He promised them that after he had won the election and become governor he would ensure that they would not be evicted from their current location. (Plans had been made to demolish the Gav Stoa settlement in order to make way for a Maritime College.) 


\section{Limited preferential voting and female candidates}

The votim asples campaign seems to have overshadowed any vote-for-women campaigns in the Madang Provincial and Madang Open electorates. As noted, Catherine Mal, a candidate who was runner up in 1997 election, stood down after a meeting of Ambenob and Transgogol candidates. Two other women contested the Open seat: Agatha Yama, wife of People's Labour Party leader Peter Yama, and Dr Cecilia Pakule. Both women's main vote base was in Madang Urban, which was shared by many candidates. They were further disadvantaged by not being asples, so the votim asples campaign went against them. In the Provincial seat Mary Kamang seemed a strong candidate because of her position as the president of the Provincial Council of Women. She was also an asples from Yabob village on the edge of the town. Kamang was relying on the women's vote and also hoped to capture preference votes. However, she was up against a field of strong candidates and did well to manage fourth place.

\section{Multiple voting}

Multiple voting is a common problem in the Highlands provinces but occurs in coastal provinces as well. A policeman providing security at a polling booth in Madang confided that he had voted more than once - most likely in collaboration with other polling officials. In parts of Madang Urban electorate scrutineers were on the lookout for people trying to vote more than once, especially by impersonating others. Two female students were caught and arrested by police (The National 5 July 2007), but generally there were few instances of multiple voting in Madang Open and Madang Provincial electorates, where scrutineers were vigilant and secret ballot voting was enforced. At Sisiak, a suburb noted at times for its lawlessness, scrutineers were actively monitoring every single voter and challenging those whom they suspected. After some minor disturbances during the day involving Highlands voters trying to pressure polling officials, there was a heavy police presence and, we were told, police locked up a number of people trying to cause trouble.

\section{Use of firearms}

During polling in Madang Urban, supporters of a prominent Highlands candidate discharged firearms at the popular Machine Gun beach, assaulted a polling official, and kidnapped a policeman. The kidnapped policeman later said he did not see any firearms in the vehicle in which he was transported but had seen bush knives, axes and other weapons. An open confrontation between the police and the candidate's supporters was averted and a security force contingent from Lae was brought in to maintain law and order. Police also reported that 
supporters of the same candidate were seen along the Ramu River, dressed in police and army uniforms, waiting to intercept ballot boxes coming down the Ramu River. However, when they realized that a policeman was escorting the ballot boxes, they jumped into the vehicle and fled. A candidate also told me that the same group of people tried to forcibly take a ballot box after polling in a remote location in Bogia but the presiding officer and an unarmed policeman guarding the polling booth prevented them.

\section{Assessing the outcome}

The introduction of LPV, according to Standish (2006:196-198) was intended primarily to address the declining mandates held by members of parliament elected under first-past-the-post voting. Its introduction was an attempt at political engineering to 'change people's electoral behaviour or political culture, and in particular to break down the intense localism found in most areas of Papua New Guinea'. He also listed other arguments for LPV, such as making campaigning more accommodative and less confrontational, lessening violence, easing tensions, giving women candidates a better chance of election, and allowing MPs to be elected with an absolute majority (though only a majority of the live votes at the final count).

Observations of the Madang Open and Madang Provincial seats revealed that some of these changes have taken place. There have been changes in people's electoral behaviour and in the political culture, especially in allowing preference sharing by candidates and their supporters. Winning candidates can also claim a majority victory. However, there has been no indication of reduced tension; indeed, the 'highlandization' of politics seems to have increased tensions somewhat in Madang, with the assault of polling officials and use of firearms on the Madang waterfront.

Women's chances have not improved at all. The votim asples campaign seems to have worked against voting for women.

Candidates who are up against a strong and popular opponent sometimes resort to smear campaigns in the hope of increasing their chances of winning. A candidate campaigning at a settlement in Madang town described his opponent, Sir Arnold Amet, as a waitman in blak skin who did not understand pasin Madang (a 'white' Papua New Guinean who did not understand the Madang culture). This unfortunate slur was used against Sir Arnold throughout Madang by his opponents. Sir Arnold was well aware of it and referred to it when giving his inauguration address after his win. However, there was popular support for the former chief justice, especially in his home electorate of Sumkar. 
People had confidence that he could use his professional skills and experience in government to bring change to Madang. Compared to Sir Arnold, the other candidates had little to offer.

\section{Addressing problems}

The issue of 'highlandization of coastal politics' can only be effectively addressed when voters become aware of what is actually going on. Some awareness took place in Madang in 2007 and candidates have used the avenues provided by LPV, such as preference sharing, to unite in addressing the issue. The asples campaign for the Madang Open and Madang Provincial seats succeeded in getting local candidates elected. There has been some grumbling among the asples candidates themselves over the eventual winner of Madang Open, whom they did not see as someone particular endowed with leadership qualities, but people will have to live with their choice.

On the other hand, there is general satisfaction with the election of Sir Arnold Amet, who many thought was the ideal candidate for the governor's position. Even his opponents acknowledge that he has brought stability to the troubled Madang governor's seat. But there is a challenge to his victory from one of the losing candidates, citing bribery, undue influence, intimidation, and errors and omissions by counting officials. Among the accusations against Amet is that more than 3000 ballot papers marked for Peter Yama were found at Meiro dump near the town. Prior to 2002 interference with ballot papers was a problem largely confined to Highlands electorates, but a similar incident occurred in Madang in 2002. The same candidate has been involved on both occasions; it was also his supporters who were involved in the attempts to hijack ballot boxes along the Ramu River and inland of Bogia in 2007. These matters need to be investigated and dealt with appropriately. The election-related use of firearms is still limited and effective police operations and the peaceful nature of the Madang people ensured that this remained the case.

Ward recorders and voters have generally worked together to avoid inflation of rolls, but the attempt to inflate the roll in Ward 5 by multiple entries of names of students at Divine Word University must be dealt with before the next election. There were attempts at multiple voting in Madang in 2007, but incidents were few and mostly controlled by the introduction of ward rolls which are easier to administer and easier for scrutineers to monitor. Proposals for permanent ward recorders to regularly update the rolls should be considered. An accurate ward roll is crucial for elections and useful for ward development and administration.

Some candidates in Madang Open and Madang Provincial seats spent large sums of money on their campaigns; this is reflected in the disputes that have 
occurred after the election. While money is an important factor, it did not seem to influence the outcome of the elections in Madang. The tendency of Madang people to vote asples candidates, and the opposition to the 'highlandization' of Madang politics, had a major influence on the election in Madang in 2007.

\section{References}

Gupta, D. and Ivarature, H., 1996. ‘Restructuring Decentralisation: Political and Economic Issues'. Paper presented at seminar organized by National Centre for Development Studies, The Australian National University and the Papua New Guinea National Research Institute.

May, R. J., 2006. 'The "clan vote" in Papua New Guinea open electorates: data from Angoram', Journal of Pacific Studies 29(1):108-129.

May, R. J. and Regan, A. J. with Ley, A., 1997. Political Decentralisation in a New State: The Experience of Provincial Government in Papua New Guinea. Bathurst: Crawford House Press.

Nelson, H., 2006. 'Governments, states and labels', State, Society and Governance in Melanesia Discussion Paper 2006/1. Canberra: State, Society and Governance in Melanesia, The Australian National University.

Sinclair, J., 2005. Madang. Madang: Divine Word University Press.

Standish, B., 2002a. 'Papua New Guinea politics: attempting to engineer the future', Development Bulletin 60:28-32.

Standish, B., 2002b. 'Papua New Guinea's 2002 National Elections'. UPNG/ANU Workshop Report, Port Moresby.

Standish, B., 2003. 'Papua New Guinea's most turbulent election', Catalyst 33(2):130-148.

Standish, B., 2006. 'Limited preferential voting in Papua New Guinea: some early lessons', Pacific Economic Bulletin 21(1):195-211.

Summer Institute of Linguistics (SIL), 2009. PNG Language Resources http://www.sil.org/pacific/png/ Accessed 19 June 2009. 


\section{Appendix}

Table 22.2: Voting statistics for Madang Open electorate, 2007 election

Number of registered voters

Total votes cast

Informal votes

Total allowable ballot papers

Total ballot papers remaining in count

Total votes distributed

Exhausted ballot papers

Absolute majority $(50 \%+1)$
53,851

36,053

931 (2.6\% of total votes cast)

35,122

15,751

21,659

19,371 (55.2\% of allowable ballots)

17,562

Table 22.3: Voting statistics for Madang Provincial electorate, 2007 election

\begin{tabular}{lrr}
\hline Number of registered voters & 224,303 \\
Total votes cast & 157,371 \\
Informal votes & $5,111 \quad$ (3.2\% of total votes cast) \\
Total allowable ballot papers & 152,260 \\
Total ballot papers remaining in count & 95,169 \\
Total votes distributed & na \\
Exhausted ballot papers & $57,091 \quad$ (37.5\% of allowable ballots) \\
Absolute majority $(50 \%+1)$ & 47,586 & \\
\hline
\end{tabular}


Election 2007: The Shift to Limited Preferential Voting in Papua New Guinea

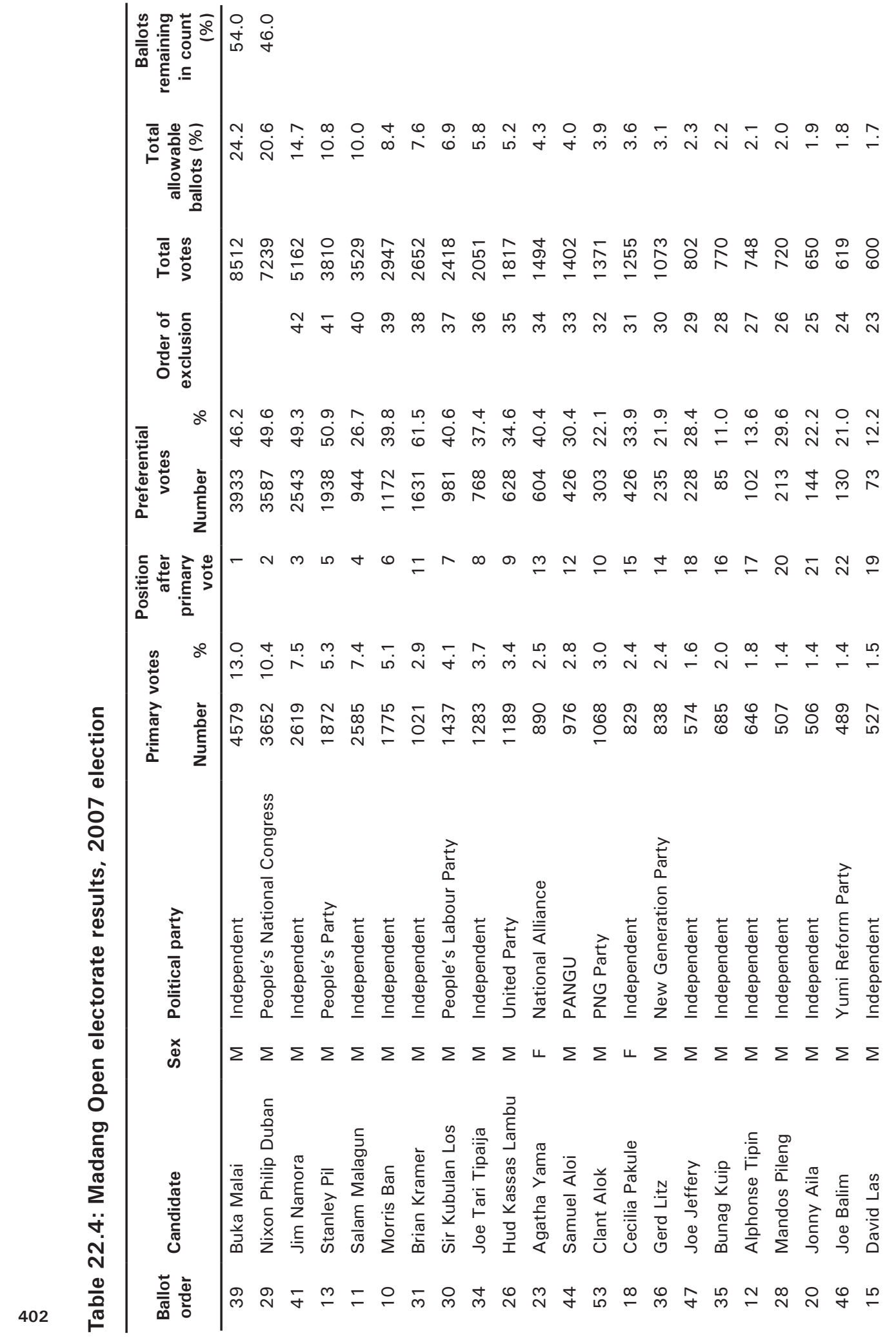


22. Elections and Corruption: The 'Highlandization' of Voting in the Madang Open and Provincial Electorates

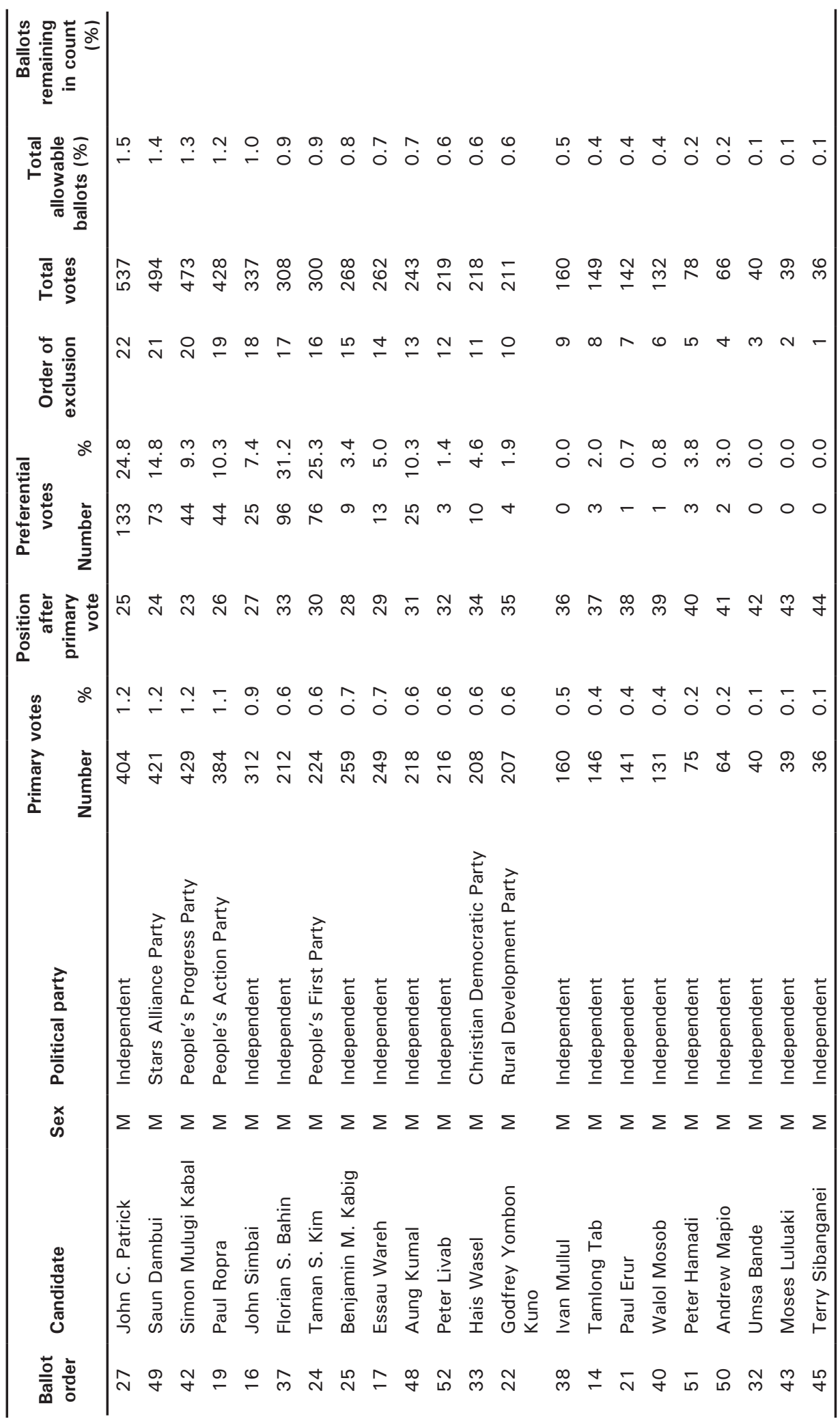


Election 2007: The Shift to Limited Preferential Voting in Papua New Guinea

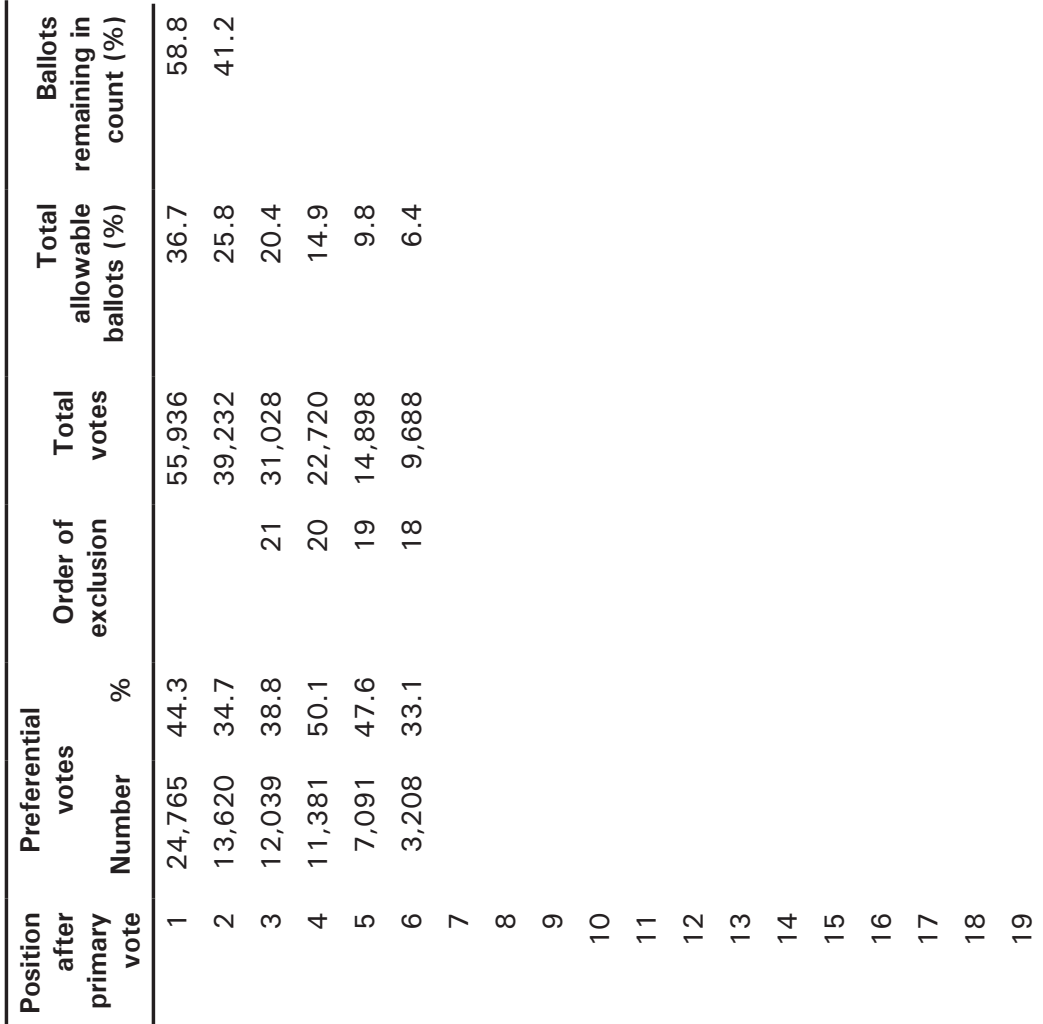

$$
\begin{aligned}
& \frac{\text { 든 }}{\frac{c}{0}} \\
& \text { ڤัे }
\end{aligned}
$$

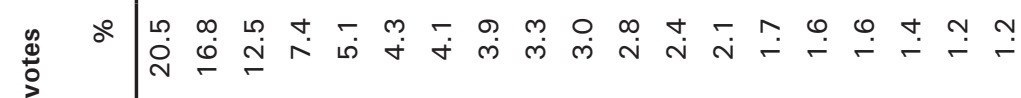

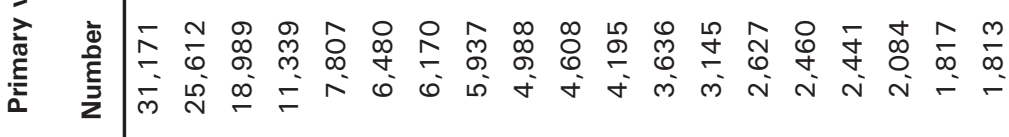

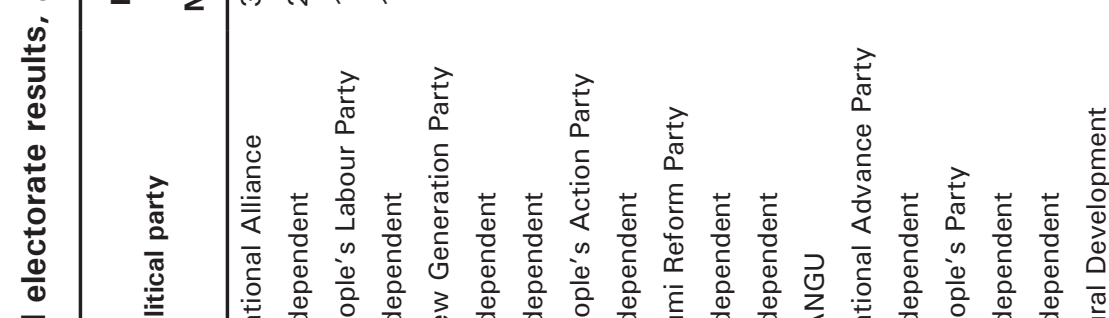

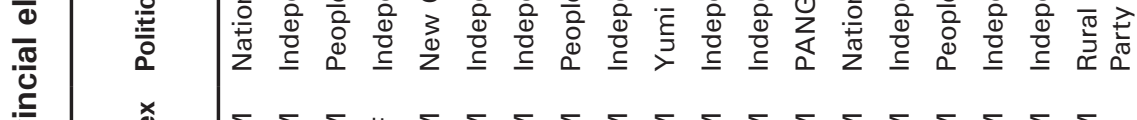

$$
\begin{aligned}
& \frac{1}{2} \\
& \frac{\sqrt{0}}{\frac{\pi}{0}} \\
& \text { œ }
\end{aligned}
$$


22. Elections and Corruption: The 'Highlandization' of Voting in the Madang Open and Provincial Electorates

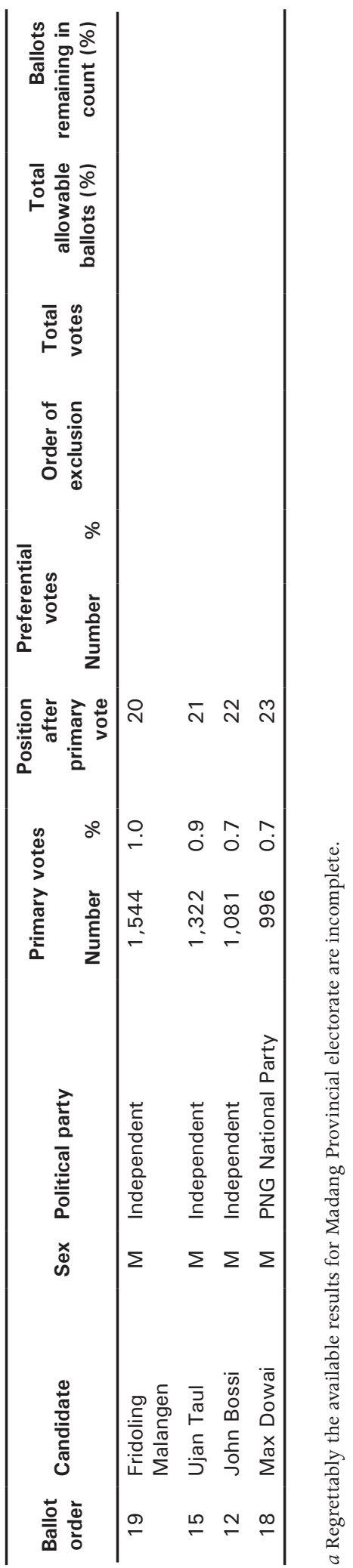

